\title{
Economic growth, urbanization, globalization, and the risks of emerging infectious diseases in China: A review
}

\author{
Tong Wu, Charles Perrings, Ann Kinzig, \\ James P. Collins, Ben A. Minteer, Peter Daszak
}

Received: 8 December 2015/Revised: 16 April 2016/Accepted: 18 July 2016/Published online: 4 August 2016

\begin{abstract}
Three interrelated world trends may be exacerbating emerging zoonotic risks: income growth, urbanization, and globalization. Income growth is associated with rising animal protein consumption in developing countries, which increases the conversion of wild lands to livestock production, and hence the probability of zoonotic emergence. Urbanization implies the greater concentration and connectedness of people, which increases the speed at which new infections are spread. Globalization - the closer integration of the world economy-has facilitated pathogen spread among countries through the growth of trade and travel. Highrisk areas for the emergence and spread of infectious disease are where these three trends intersect with predisposing socioecological conditions including the presence of wild disease reservoirs, agricultural practices that increase contact between wildlife and livestock, and cultural practices that increase contact between humans, wildlife, and livestock. Such an intersection occurs in China, which has been a "cradle" of zoonoses from the Black Death to avian influenza and SARS. Disease management in China is thus critical to the mitigation of global zoonotic risks.
\end{abstract}

Keywords Avian influenza · China ·

Emerging infectious diseases - Globalization ·

Urbanization $\cdot$ Zoonosis

\section{INTRODUCTION}

Today, an increasingly urban and interconnected world faces growing threats from emerging infectious diseases (McMichael 2004; Kapan et al. 2006; Bradley and Altizer 2007). This is of particular concern in the developing world, where managing fast-spreading epidemics in the growing number of megacities is a pressing challenge (Rees 2013). Recent epidemics have underscored the importance of linkages between host habitats and the global network of cities. The Ebola virus, for example, has long survived among wildlife reservoirs in the hinterlands of Africa, "breaking out" in towns and cities in conspicuous but otherwise local epidemics. As in earlier outbreaks, the 2014 epidemic is thought to have origins in the consumption of wild animal protein, while its spread occurred in densely populated African cities. The international threat it posed stemmed from the increasing air travel connections between these and other cities around the world.

In the case of arboviruses like Zika, dengue, chikungunya, West Nile, and malaria, whose vectors have found ready habitat in urban areas, the primary mechanism for the spread of disease from one city to the next is international trade and travel (Hay et al. 2005; Tatem et al. 2006; Alirol et al. 2011; Weaver 2013; Kraemer et al. 2015). The same is true of coronaviruses such as Severe Acute Respiratory Syndrome (SARS) and Middle Eastern Respiratory Syndrome (MERS). The latter emerged in Saudi Arabia in 2012, having been transmitted between animal reservoirs such as camels and their human handlers. It has since spread throughout the surrounding region, and travel-related human infections have been recorded in Europe, North America, and East and Southeast Asia (Parlak 2015; Zumla et al. 2015). Urbanization and globalization have made outbreaks of these diverse zoonoses difficult to control, even with unprecedented levels of international cooperation (Khan et al. 2013; Weaver 2013; Chan 2014; Kraemer et al. 2015).

For most emerging infectious diseases, prevention is better than cure-ex ante mitigation of disease risk is more economically efficient than ex post adaptation to an 
outbreak (Murphy 1999; Graham et al. 2008; Voyles et al. 2014; Langwig et al. 2015). Among mitigation strategies, vaccination has been a widespread and long-established practice for many DNA viruses such as chicken pox or small pox. However, vaccination remains problematic for most RNA viruses, including Ebola, SARS, and avian influenza, due to their higher mutation rate; vaccination is simply not a feasible way to prevent the emergence of many novel zoonoses, which will inevitably encounter immunologically naïve populations. Therefore, mitigating the risks from emerging and reemerging zoonoses requires preemptive measures against their socioecological drivers (Pike et al. 2014). Identifying areas where the convergence of risk factors is occurring with greatest intensity, and at the largest scales, is a logical first step in the development of a mitigation strategy. In this regard, China may be an important outlier among countries.

Assessment of the risks posed by zoonotic diseases requires an understanding of how socioeconomic, and ecological conditions affect two phenomena: emergence (the irruption of a pathogen originating in wildlife or livestock into human populations) and spread (the transmission of disease among both animals and people). In this article, we review the evidence for changes in zoonotic risks in China. More particularly, we show how income growth, urbanization, and globalization affect the likelihood of emergence and spread, using SARS and avian influenza as topical and representative examples, but also referring to other diseases when relevant. We discuss the policy implications of changes in the epidemiological environment in China, and consider how the mitigation of zoonotic risk in China could benefit the global risk environment.

China's rate of economic growth over the last 25 years has been exceptional. Real per-capita GDP (in purchasing power parity terms) rose from 1516 USD in 1990 to 12608 USD in 2014, an average annual growth rate of over $9 \%$. While this has generated the resources necessary to improve biosecurity and healthcare, it has also increased the likelihood of disease emergence and transmission. The presence of major migratory bird pathways (conduits for the transmission of influenzas), habitats that encourage mixing between wild and domesticated birds, and a dramatic increase in demand for fresh meat have increased the likelihood of disease emergence. At the same time, urbanization and the growth of international trade and travel have increased the likelihood of disease spread (Wang et al. 2008; Alirol et al. 2011; Zhu et al. 2011; Gong et al. 2012; Li et al. 2012a, b). In 1990, only one quarter of China's population lived in cities; today, over $54 \%$ are urban residents, and by 2030 there will be at least one billion city-dwellers, or $70 \%$ of the population (Peng, 2011). Concurrently, China's integration into international networks of trade and travel has occurred rapidly. Between 1990 and 2015, China's exports to the rest of the world grew annually by around $17 \%$, and although exports in this period were dominated by manufactures, exports of food and live animals grew at an only slightly lower rate. More importantly for China's exposure to global disease risk, imports of food and live animals were 7-8 times larger than exports in 1990, and have since grown by around $15 \%$ year (World Bank 2016).

\section{ECONOMIC GROWTH, MEAT CONSUMPTION, AND ZOONOTIC RISKS IN CHINA}

The epidemiological boundary separating humans from wildlife- and livestock-borne pathogens has been breached repeatedly throughout history. At the turn of the twentieth century, it was estimated that $61 \%$ of all known human pathogens and $75 \%$ of all emerging diseases were zoonotic (Taylor et al. 2001). Zoonotic "spillover" into human populations can occur in numerous ways. Direct contact between people and pathogen-carrying animals through, for example, the consumption of infected wildlife or livestock is a common pathway of emergence (Patz et al. 2004; Murray and Daszak 2013).

Increasing per-capita income has led to increasing percapita meat consumption, and this has occurred more rapidly in China than in any other major economy. Tracking rapid rates of GDP growth and rural-to-urban migration, China's meat consumption has risen by around one-third since the turn of the century (Fig. 1). The pattern of consumption is also changing: while pork remains the main source of animal protein, chicken consumption and production are increasing more rapidly. Between 1968 and 2005 , the growth in poultry numbers was around ten times the growth in pig numbers (Wang et al. 2008). Nor has the growth rate of these stocks slowed. In 2013, China had the world's largest stocks of poultry and swine, at 6.63 billion and 482 million individuals, respectively. By comparison, U.S. stocks stood at 2.16 billion and 64.8 million individuals (FAO 2015).

What makes the changing pattern of meat consumption significant for infectious disease transmission in China is a persisting social preference for live and freshly slaughtered meat (the primary interface for animal-to-human transmission of many zoonoses) (Pi et al. 2014). As the consumption of meat grows in the coming decades, so will contact between consumers and live or freshly slaughtered animals. Over the next decade, per-capita consumption of chicken is expected to grow at an annual rate of $2.4 \%$, compared to $1.5 \%$ for pork. While meat imports will likely increase, most of the growth in supply is expected to be from domestic sources. Annual production of poultry, pork, 
(a) live poultry stocks

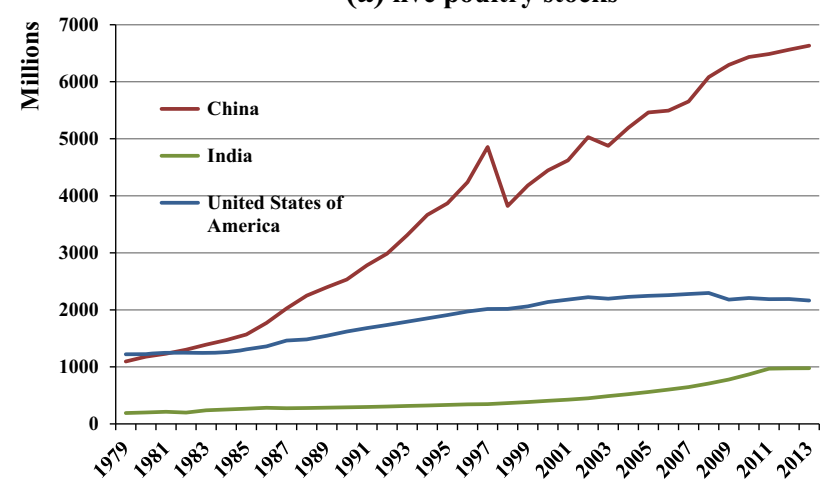

(b) live pig stocks

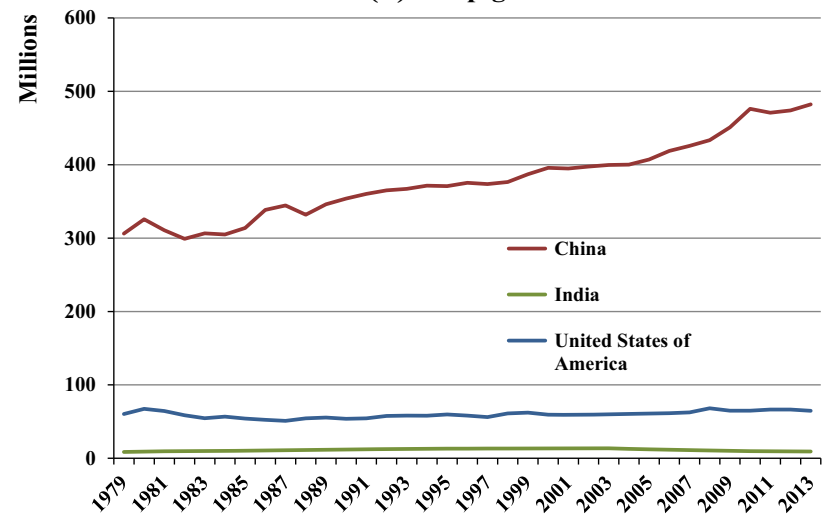

Fig. 1 Growth of China's poultry (a) and pig (b) stocks since 1979, compared to India and the United States

and beef is projected to rise from 70 million metric tons (mmt) today to $90 \mathrm{mmt}$ by 2024 (Westcott and Trostle 2014). The resulting increase in the levels and densities of pigs and poultry enlarges the potential pathogen reservoirs for zoonoses, especially influenzas.

A central mechanism that brings human, livestock, and wild animal populations together in China is the extensive network of wet markets-markets that sell live and freshly slaughtered domesticated and wild animals. Although found in many parts of the world, wet markets are particularly common in East and Southeast Asia. In China, they are the primary source of meat purchases, particularly of poultry. In Shanghai, for example, where highly pathogenic avian influenza (HPAI) H7N9 first emerged in 2013, 120 million of the approximately 190 million chickens consumed annually were purchased at wet markets ( $\mathrm{Pi}$ et al. 2014).

The spillover of H5N1 and H7N9 into human populations in China has been closely linked to these markets ( $\mathrm{Yu}$ et al. 2007, 2014). Wet markets are frequently underregulated, have unhygienic environments with inadequate sanitation, and are subject to poor surveillance and little biosecurity (Woo et al. 2006). Although the role of wet markets is expected to diminish in the coming decades, they will still account for a significant, perhaps even the majority, share of poultry sales (Pi et al. 2014). Income growth among urban consumers will increase the demand for meat, much of it bought in wet markets. Indeed, dietary preference for freshly slaughtered meat and the enduring popularity of wet markets will remain important drivers of zoonotic risk for the foreseeable future.

\section{URBANIZATION AND DISEASE SPREAD}

The growth of cities and changing agricultural conditions have shaped infectious disease ecology in China since at least the Tang Dynasty (seventh to tenth century CE), creating and connecting reservoirs of pathogens and vectors (Jannetta 1993). However, the speed and scope of urbanization over the past three decades have been significantly greater than at any other time in the past, creating a primarily urban population for the first time in China's history. The rate of urbanization has also been markedly higher than that of other industrialized and industrializing countries. For instance, in 1979, at the start of its own economic liberalization program, India had an urbanization level of $18.6 \%$ compared to China's $22.7 \%$. Today, China's urbanization has reached $54.4 \%$ compared to India's $32.4 \%$ (UN 2015).

In China, this has expanded the interface of contact between humans, wildlife, and livestock. Urbanization and associated land-use changes, in conjunction with rising meat consumption, have brought reservoirs of wildlife diseases into closer contact with livestock and people (Wang et al. 2008; Daszak 2000; Daszak et al. 2001; Myers et al. 2013). In particular, the emergence of HPAI strains has become more likely in southern China, where the growth of an increasingly affluent urban population has driven an increase in poultry production and land-use changes that brings humans, domesticated animals, and wildlife into closer contact (Davis 2005; Wallace et al. 2010) (Fig. 2).

Changes in the configuration of natural, agricultural, and built-up land cover, as well as in the biotic and abiotic fluxes among them, also affect disease risks to people (Reisen 2010; Meentemeyer et al. 2012). Large and growing populations of livestock-particularly poultrydistributed across China are ideal sites of viral mutation and interspecies influenza transmission, most notably between wild and domesticated birds. China is also crossed by multiple migratory flyways, which allow numerous waterfowl and other bird species to carry avian influenza into and out of the country (Chen et al. 2005; Kilpatrick et al. 2006; Takekawa et al. 2010; Prosser et al. 2011). Across East Asia, intensively cultivated rice fields are populated by poultry and ducks, but are also ready habitats 


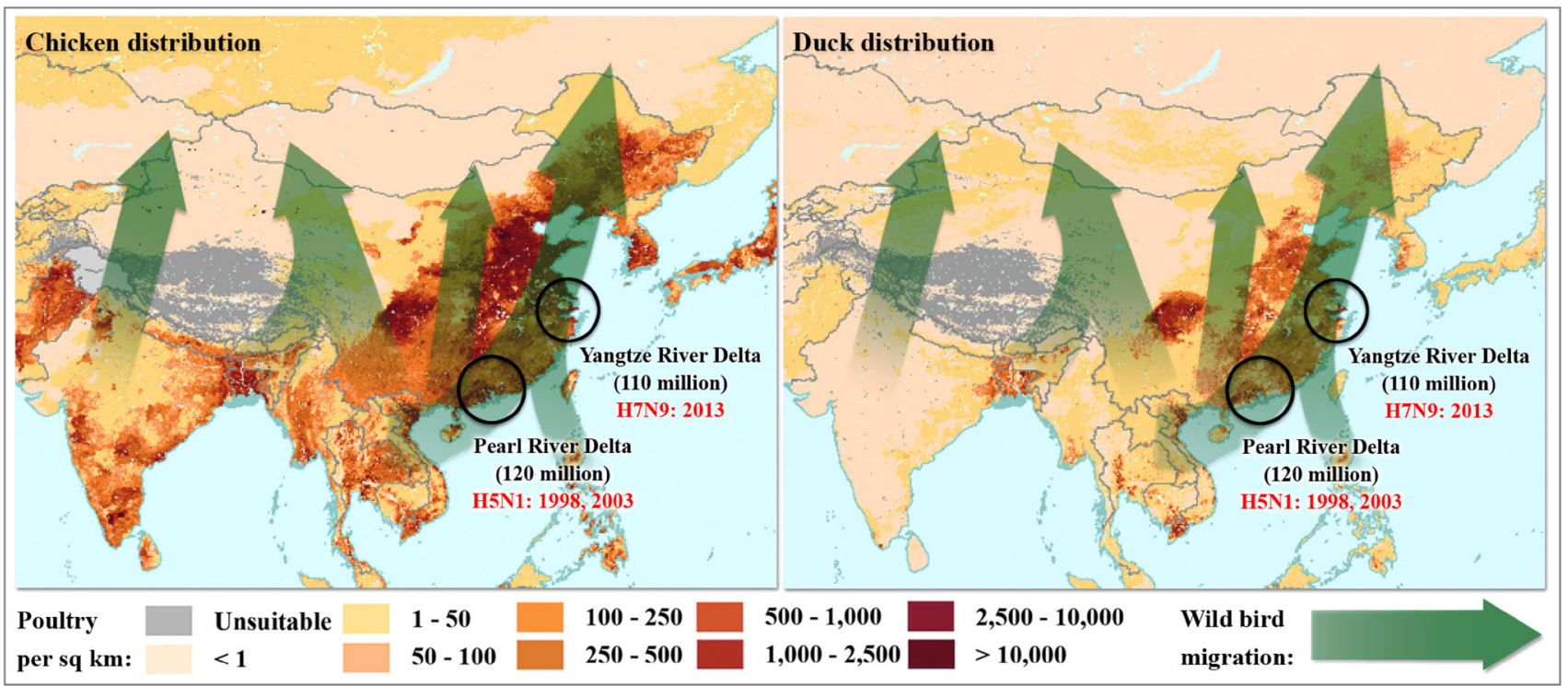

Fig. 2 The intersection of dense chicken and duck populations, human populations (concentrated by urbanization), and migratory birds increases the likelihood of interspecies transmission and the emergence of new influenza strains. Sources Generalized bird migration routes adapted from Fang et al. (2008); poultry distribution data from Robinson et al. (2014)

for HPAI-carrying waterfowl (Gilbert et al. 2008; Paul et al. 2010; Martin et al. 2011; Gilbert et al. 2014) (Fig. 2). The growing number of species infected by recent outbreaks of avian influenza suggests that epidemic risks are growing as a result (Webby and Webstter 2003). Livestock populations are also staging posts for pathogens to enter human populations. For instance, poultry farming in China's urban and peri-urban areas increases the likelihood of H5N1 spread (Kapan et al. 2006; Fasina et al. 2007).

The risk of pathogen spread from diseases contracted in wet markets is exacerbated by the concentration and interconnectedness of human populations associated with urbanization (Fang et al. 2008; Hogerwerf et al. 2010; Paul et al. 2010). Wet markets in urban areas are now recognized to be the primary locus of infection for H7N9 (Gilbert et al. 2014). The high density of people makes cities, particularly the large cities that have appeared rapidly in China, force multipliers of pathogen transmission (Alirol et al. 2011). Patel and Burke (2009) argue that the outbreak of SARS in Hong Kong in 2002 and 2003 "demonstrated how dense urban living could ignite a global health crisis." The first phase of the SARS epidemic involved its spread through the interconnected metropolises of the Pearl River Delta (PRD) (Wang et al. 2008; Zhu et al. 2011; Li et al. 2012b). The PRD was also an epicenter for HPAI H5N1 (see Box 1) and remains a potential hotspot for other influenzas (Fig. 3), though this has yet to be reflected in public health policies in the area (Fabre and Rodwin 2011).

One reason for the effectiveness of cities as force multipliers, relative to rural areas, is the higher prevalence of a range of communicable and noncommunicable diseases, including sexually transmitted diseases and cancers. Such conditions increase vulnerability to infection (Alirol et al. 2011; Gong et al. 2012; Li et al. 2012b), while comorbidity can magnify the potential virulence of zoonotic pathogens and thus their spread (Weiss and McMichael 2004). In many Chinese cities, public health management has not kept pace with demographic and economic changes. Despite progress in recent decades, immunization coverage for even common infections such as tuberculosis, measles, and tetanus remains inadequate (Gong et al. 2012). Infection risk is also related to the social inequality and dislocations caused by urbanization. In the Pearl River Delta in 2009 , for instance, $80 \%$ of migrants did not have access to medical insurance (Fabre and Rodwin 2011). This deprivation may deter people from seeking preventative care, or even immediate care after possible infection.

\section{CHINA AND THE GLOBALIZATION OF INFECTIOUS DISEASE RISKS}

The epidemiological implications of disease comorbidityincluding the risks of "super-spreaders"- are perhaps even more significant at the international level. For instance, had the first SARS carrier reached the dense precincts of Durban, with its high incidence of AIDS, rather than the more ordered and hygienic environment of Toronto, the outcome may have been much worse (Weiss and McMichael 2004). Of course, the probability that an infection is transmitted abroad to a given city depends on the volume of trade and travel involved, but since trade between China 
Box 1 HPAI and China's urbanization

HPAI H5N1 first emerged in southern China in the late 1990s. After several outbreaks, contained with varying degrees of efficacy, it has now spread across the world, infecting people, poultry, wild birds, and other wild and domesticated animals. Income growth has driven an increase in China's protein consumption, which has resulted in a nearly 6-fold increase in domestic poultry stocks since 1979 (FAO 2015). Urban wet markets are still the primary sources of poultry purchases-in Shanghai, for instance, 120 million of the 190 million chickens sold in 2013 were from wet markets (Pi et al. 2014). That year, Shanghai, China's largest city at 25 million people, was the site of HPAI H7N9's emergence. The most likely areas of future H7N9 spread in China are urban areas with a high density of wet markets (Gilbert et al. 2014). China is also traversed by several migratory bird pathways, bringing growing and ever-denser populations of poultry and people into contact with influenza-bearing wild birds (Chen et al. 2005; Takekawa et al. 2010). The heavily urbanized areas of southern China—such as the metropolitan Pearl River Delta, home to over 100 million people and a high concentration of poultry production - is at particular risk for the emergence of HPAI, and may be an important outlet for its spread within China and internationally (Davis 2005; Wallace et al. 2010)

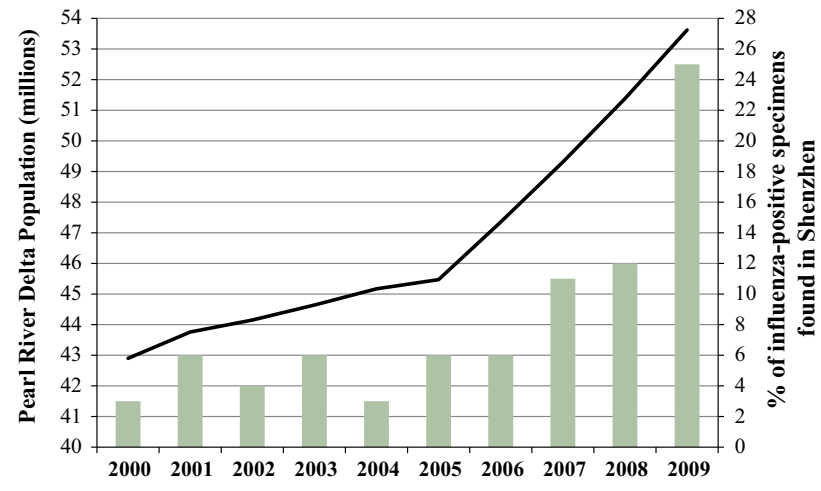

Fig. 3 The increasing population of the Pearl River Delta urban area (black) and the annual rise in influenza-positive specimens from Shenzhen, one of its primary cities (gray). Sources Urbanization data from Bureau of Statistics of Guangdong Province (2013); Shenzhen influenza-positive specimen data from Cheng et al. (2013)

and South Africa has been growing more rapidly than trade with China's main international markets, this is not a trivial observation. China is now the world's largest trading nation, and in recent years its trade to nearly every region of the world has increased significantly (Fig. 4). The global infectious disease risks created by China's trade growth stem from the fact that international markets facilitate the movement of pathogens around the world as freely as commodities and people (Perrings et al. 2005; Knobler et al. 2006; Tatem et al. 2006; Hulme 2009; Perrings 2010; Kilpatrick 2011).

In history, there have been several notable moments when trade and travel have bridged the natural epidemiological discontinuities created by geography. The most famous of these is the Black Death of the thirteenth and fourteenth centuries, during which the plague bacillus Yersinia pestis spread from China to Europe along trade routes maintained by the Mongol Empire. The same disease had also earlier spread across Eurasia from China in the sixth century (Wagner et al. 2014). That outbreak, known as the Plague of Justinian, had killed tens of millions across the Mediterranean region and critically damaged the economic and geopolitical fortunes of the Byzantine Empire (McNeill 1998). Not all epidemics have Chinese origins, though. Several centuries later, overseas expansion by European powers led not only to the political and economic subjugation of foreign peoples, but also to the introduction of many new species-pests and pathogens among them (Crosby 1986). The growth of maritime trade facilitated massive movements of people, plants, and animals, as well as the pathogens that these passengers and cargo carried, across the world's oceans. The so-called Columbian Exchange had particularly severe effects on human health on both sides of the Atlantic. Old World diseases such as smallpox, typhoid, typhus, and measles were introduced to the Western Hemisphere by colonizers, resulting in significant depopulation and a decisive shift in the balance of power (McNeill 1998; Diamond 1999; Crosby 2003).

Nevertheless, China has remained a persistent and important source of infectious zoonotic disease. For instance, a plague outbreak in southwestern China engulfed the country and then spread to the rest of the world in the late 1800 s. The spillover was likely mediated by rat-borne fleas, brought into contact with people due to ecological encroachments from settlement expansion (Benedict 1996). This plague first spread to the port cities of the Chinese coast and thence to Southeast Asia, the United States, and Europe. In the western U.S., the bacillus remained epizootic among rodent species well into the twentieth century (McNeill 1998).

The archetypal modern pandemic - the one that remains a touchstone for thinking about global infectious disease risk-is the 1918-1919 Spanish Flu. The severity of this pandemic was in large part a result of the integration forced by global conflict. Propagated by the movements of millions of servicemen during and after World War I, this strain of H1N1 influenza may have infected as many as 500 million people, or a quarter of the world's population, and killed as many as 50-100 million (Taubenberger and 


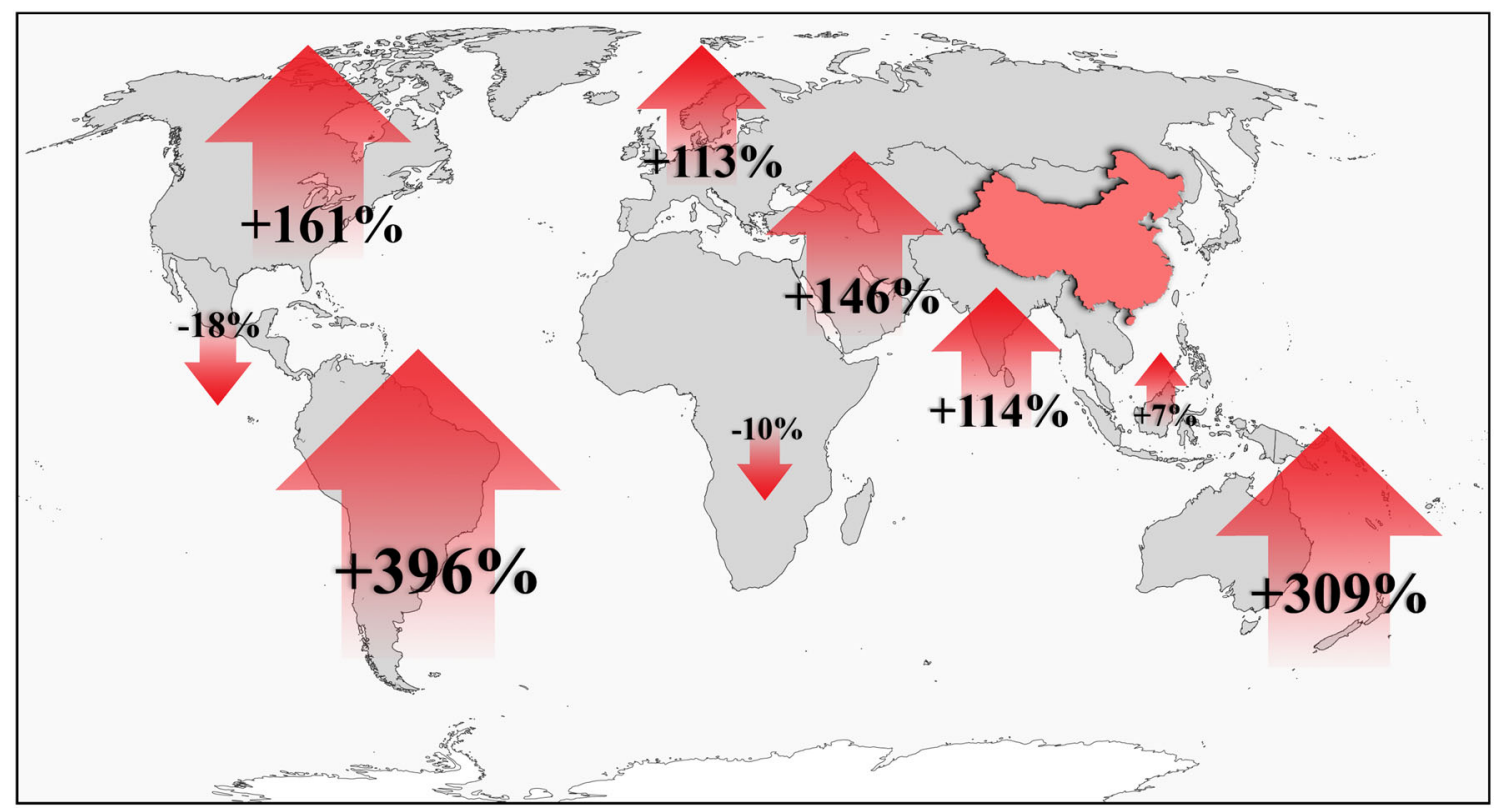

Fig. 4 The percent increase in the volume of commodities exported from mainland China to different global regions between 2001 and 2011. Source Food and Agriculture Organization (http://www.faostat.org/)

Morens 2006). Recent forensic studies tracking mortality rates and other contemporary evidence suggest that, contrary to its name, this pandemic actually originated in China (Langford 2005; Humphries 2014). Indeed, China has been the epicenter of influenza both before and after the "Spanish Flu." At least two of four historically documented pandemics originated in China before 1918, as did both of the subsequent pandemics (Potter 2001) (Fig. 5).
The mechanism behind the global spread of diseases after 1918 has been the ever-closer integration of the world economy. Habitat suitability and transport distance determine the potential dispersal patterns of infectious disease vectors (Tatem et al. 2006), while the relative costs and benefits of trade and infectious disease determine the likelihood that pathogens will be spread this way (Perrings 2014). The potentially high cost of the SARS epidemic led

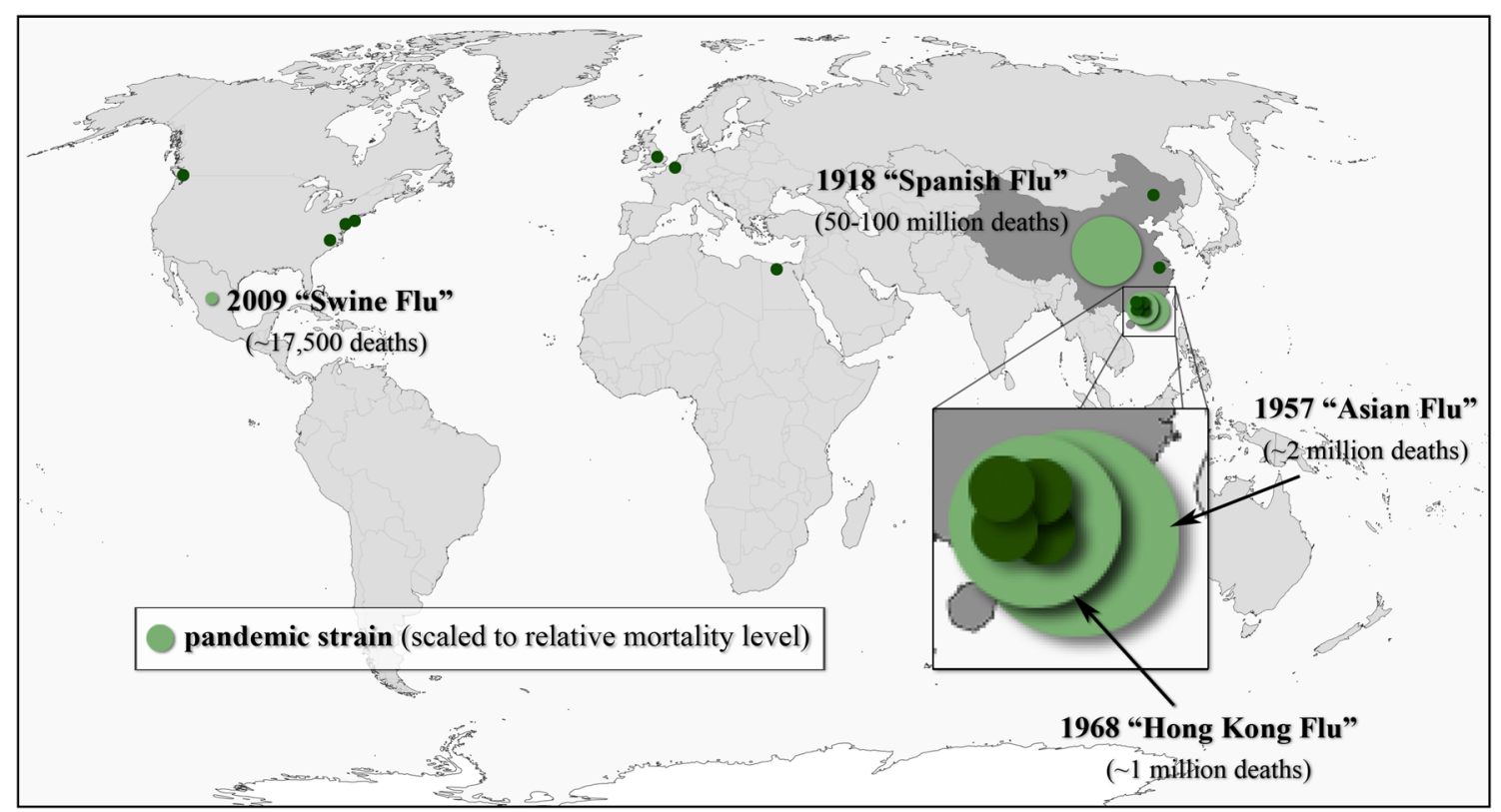

Fig. 5 The geographic distribution of confirmed outbreaks of novel and/or pandemic influenza strains since 1900. Of the four pandemic strains, three emerged in China. Adapted from: http://www.niaid.nih.gov/topics/Flu/Research/Pandemic/Pages/TimelineHumanPandemics.aspx 
to prompt preventive action, but the volume of travel meant that the pathogen still managed to reach every continent. In East Asia alone, SARS resulted in at least a $2 \%$ decline of GDP (Brahmbhatt 2005). It has been estimated that the economic losses from a major influenza pandemic could be as high as $\$ 7.3$ trillion (12.6\% of global GDP) - a downturn on par with the Great Depression-and cause over 140 million deaths (McKibbin and Sidorenko 2006).

\section{POLICY IMPLICATIONS OF CHINA'S ZOONOTIC DISEASE RISKS}

Given its role as the "cradle of influenza" (Davis 2005), and many other zoonoses, China should be a focus of international efforts to mitigate future infectious disease risk. It is likely that the factors that facilitated the global spread of the 1894 plague and the 1918-1919, 1957, and 1968 influenza pandemics that originated in China are even more forceful today. The lesson of recent decades is that zoonoses such as HPAI, SARS, and Ebola cannot be reliably contained at the local, national, or even continental level. It follows that infectious disease risk mitigation is a product not only of the probability of emergence, but also of the probability that an outbreak will be propagated to other parts of the world.

Design and implementation of risk mitigation strategies require an understanding of the factors affecting the probability that zoonoses will emerge, and the likely pattern of their spread (McMichael 1999; Daszak et al. 2001; McMichael 2004; Daszak 2005; Castillo-Chavez et al. 2015). With regard to China, in particular, this involves understanding the way that income growth, urbanization, and globalization interact with predisposing socioecological conditions (including changes in the interface between wild and domestic species, and cultural practices surrounding the consumption of those species) to alter the likelihood of emergence.

We also need an improved understanding of the role of more widespread processes in changing epidemiological environments. Climate change is expected to alter ecosystem processes and functioning in ways that will influence the emergence and reemergence of infectious diseases worldwide (Morens et al. 2004; Piao et al. 2010), particularly for vector-borne pathogens (Hales et al. 1999; Chretien et al. 2015). In China, climate change, including changes in the El Nino-Southern Oscillation (ENSO), is expected to increase human vulnerability to a spectrum of infectious diseases such malaria, dengue, and Japanese encephalitis (Bi et al. 2005; Bai et al. 2013). Mitigating the infectious disease risks of climate change-both for vectorborne and directly transmissible zoonoses-requires a deeper understanding of how it interacts with urbanization and globalization to alter the vulnerability of human populations (Tong et al. 2015). Encouragingly, a recent survey of provincial public health workers in China found that the large majority had "accurate" (i.e., in line with existing scientific consensus) perceptions and knowledge about climate change and its likely impacts on infectious diseases (Wei et al. 2014).

A second requirement for successful policy is to look beyond standard epidemiological measures for risk indicators. For avian influenza, outbreaks among wild birds, poultry, and people reveal patterns that suggest new indicators (Fig. 2). The urban areas bestriding the Pearl River and Yangtze River deltas were the emergence areas for H5N1 and H7N9, respectively. Empirical studies have shown how both outbreaks were facilitated by similar socioecological changes (as discussed in preceding sections). Because of this, it has been argued that wet markets could be used as an early-warning system to detect emerging zoonoses (Webster 2004), and that control measures could focus on the norms and incentives underlying human-to-animal interactions in the marketplace (Goldman et al. 1999; Woo et al. 2006; Gao 2014; Pi et al. 2014).

A third requirement is to enable public health infrastructures to respond to a range of threat indicators. SARS and HPAI, and the experiences of dealing with other zoonotic risks in recent years, have motivated Chinese policymakers to improve their capacity to respond to emerging infectious diseases. Responsiveness, information dissemination, and infectious disease surveillance have all improved since the initial SARS and H5N1 outbreaks (Wang et al. 2008). The Ministry of Health has created the world's largest online, real-time, case-based reporting system, called the China Information System for Disease Control and Prevention, with coverage from the national down to the county level (Wang et al. 2008; Gong et al. 2012; Li et al. 2012a, b). This system is connected to a network of Center for Disease Control and Prevention (CDC) institutes (http://www.chinacdc.cn/en), which collaborates with government-funded labs and other academic organizations focused on zoonotic diseases (Wang et al. 2008; Zhang et al. 2008). As of 2014, there were 3490 CDC institutes across China (NBS 2015). Nonetheless, surveillance and the overall public health infrastructure still have several weaknesses, namely undercoverage of rural areas (where zoonoses, particularly those borne by livestock, may originate), lack of training for health professionals in poorer areas, and a low per-capita level of funding (Tong et al. 2015).

Indeed, these weaknesses may have been reflected in the fact that management of zoonotic diseases has largely been ad hoc. The reactions to HPAI outbreaks included widespread wet market closures and trade restrictions. While 
this limited the spread of H7N9 after its initial occurrence (Webster 2004; He et al. 2014; Yu et al. 2014), it was also very costly to authorities, vendors, and consumers, and is unsustainable as a policy framework for the long run (Gao 2014). Additionally, given the significant traditional values attached to wet markets and the live animal trade, policies of that kind may abrade cultural sensibilities. For instance, abrupt and prolonged closures of live animal markets may deprive people of a traditional venue for social interaction (Goldman et al. 1999; Woo et al. 2006; Gao 2014). Improving public awareness and knowledge has been one form of intervention, but more generally management has tended to take the form of response rather than prevention. But given the changing zoonotic risks, mitigation (e.g., management at the human-animal-wildlife interface in anticipation of mutation and spillover) is likely to be more cost effective than adaptation (e.g., reducing contact rates through social distancing and trade and travel restrictions after an outbreak) (Pike et al. 2014).

A fourth requirement is to build the collective capacity to mitigate international risk. Evidence that this has received higher priority in recent times is China's greater involvement in World Health Organization (WHO) initiatives (Wang et al. 2008; Zhang et al. 2008). The U.S. Agency for International Development also has active programs in China assessing the risks of emerging zoonoses (e.g., the Emerging Pandemic Threats program: http://www.usaid.gov/ept2/). Such ventures may provide an important medium for "science diplomacy"-i.e., using research collaboration and the exchange of ideas as a platform to improve geopolitical relationships-between the two largest economies, and trading nations, in the world (Hoetz 2012). Additionally, Chinese health workers have, since 2001, received training from the WHO and the U.S. Center for Disease Control, although as of 2014 only 194 had graduated from the program (Tong et al. 2015). As with domestic disease surveillance and management efforts, this has implications for the allocation of resources needed to support initiatives and institutions.

Finally, the underlying research efforts to model risk at different spatial scales and inform policy need to include factors that affect not only the abundance of susceptible, latent, infectious, and recovered individuals, but also the likelihood of contact and transmission. There would be value in exploiting a class of models in economic epidemiology that addresses the decisions made by people and policymakers that affect the likelihood of both host contact and infectious disease transmission (Perrings et al. 2014). Income growth, rising trade in goods and services, and the demographic and land-use changes caused by urbanization all affect private infectious disease risk management, and so should inform the public response. The development of infectious disease models for China that capture such risk factors would have the potential both to enhance management domestically, and to comprehend the risks from trade and travel links with the rest of the world.

In certain respects, the nature of infectious disease risk mitigation is similar to the nature of climate change mitigation. In both cases, there is a closing window for timely action. In both cases, too, the mitigation of global risk depends heavily on the efforts of a small number of countries, each of which has a disproportionate impact on global risk (Pike et al. 2014). To that end, improving the management of infectious disease risk in China is a necessary, though not sufficient, condition for managing such risks globally.

\section{CONCLUDING REMARKS}

It has been argued that the world has been undergoing an epidemiological transition, in which rising incomes and the dissemination of improved technologies and good practices has shifted the burden of disease away from communicable toward noncommunicable diseases (McKeown 2009; Sepulveda and Murray 2014). In part, this is because development generates greater resources for biosecurity and the prevention and treatment of infectious disease. There is ample evidence that an epidemiological transition is underway in China. Rising affluence has lessened the burden of infections that once were socially devastating, such as malaria and tuberculosis, but has increased noncommunicable diseases, such as cancer, heart disease, and obesity (Yang et al. 2008). At the same time, globalization has increased the potential for domestic infections to be exported to countries where infectious diseases are still the greater part of the disease burden (Bygbjerg 2012). Indeed, emerging infectious diseases have been identified as one of a few "catastrophic risks" facing humanity in the twentyfirst century, especially for developing countries (Rees 2013). In China - which, despite its remarkable development in recent decades, remains an "emerging" economy-novel zoonotic risks have accompanied the classic health trends of the epidemiological transition (Cook and Drummer 2004).

Large developing countries such as India, Indonesia, and Nigeria have a similar set of predisposing socioecological risk factors to China-e.g., large and growing human and livestock populations, high levels of interaction between species, and large-scale ecological change. As the forces of economic modernization accelerate, so could the zoonotic risks that such countries face. Unlike China, many of these countries are still in the early stages of the epidemiological transition. While they are becoming more exposed to disease risk through the growth of trade and travel, they still experience many of the public health conditions that 
increase vulnerability to infections. For instance, "silent epidemics"-i.e., those caused by high-risk pathogens that have not received international attention, and that are only pervasive at a local scale-may yet flare into epidemics of global impact. A salient example is buffalopox, an emerging and reemerging zoonosis that has recorded many animal outbreaks and human cases in South Asia. The pathogen dynamics indicate a reasonably high level of transmissibility between livestock and people, and the forces of income growth, urbanization, and globalization could contribute to its further spread (Singh et al. 2007; Venkatesan et al. 2010).

The degree to which China's public health authorities and researchers, along with their international collaborators, keep pace with income growth, urbanization, and globalization-and how these changes interact with China's predisposing socioecological conditions-will be a major force shaping global epidemiology. China is not the only emerging infectious disease hotspot, but it is among the most important. As the world continues to navigate a potentially new era for infectious diseases, the management of risk in China will be critical to the management of risk everywhere.

Acknowledgments This publication was made possible by grant \#1R01GM100471-01 from the National Institute of General Medical Sciences (NIGMS) at the National Institutes of Health.

\section{REFERENCES}

Alirol, E., L. Getaz, B. Stoll, F. Chappuis, and L. Loutan. 2011. Urbanisation and infectious diseases in a globalised world. The Lancet Infectious Diseases 11: 131-141.

Bai, L., L.C. Morton, and Q. Liu. 2013. Climate change and mosquito-borne diseases in China: A review. Globalization and Health 9: 10.

Benedict, C. 1996. Bubonic plague in nineteenth century China. Stanford, CA: Stanford University Press.

Bi, P., K.A. Parton, and S. Tong. 2005. El Nino-Southern Oscillation and vector-borne diseases in Anhui, China. Vector Borne Zoonotic Diseases 5: 95-100.

Bradley, C.A., and S. Altizer. 2007. Urbanization and the ecology of wildlife diseases. Trends in Ecology \& Evolution 22: 95-102.

Brahmbhatt, M. 2005. Avian and human pandemic influenza: Economic and social impacts. Geneva: World Health Organization.

Bureau of Statistics of Guangdong Province. 2013. Guangdong statistical yearbook 2013. Beijing: China Statistics Press.

Bygbjerg, I.C. 2012. Double burden of noncommunicable and infectious diseases in developing countries. Science 337: $1499-1501$.

Castillo-Chavez, C., R. Curtiss, P. Daszak, S.A. Levin, O. PattersonLomba, C. Perrings, G. Poste, and S. Towers. 2015. Beyond Ebola: Lessons to mitigate future pandemics. The Lancet Global Health 3: e354-e355.

Chan, M. 2014. Ebola virus disease in West Africa-No early end to the outbreak. The New England Journal of Medicine 371: 1184-1185.
Chen, H., G.J. Smith, S.Y. Zhang, K. Qin, J. Wang, K.S. Li, R.G. Webster, J.S. Peiris, et al. 2005. Avian flu: H5N1 virus outbreak in migratory waterfowl. Nature 436: 191-192.

Cheng, X., Y. Tan, M. He, T.T.Y. Lam, X. Lu, C. Viboud, J. He, S. Zhang, J. Lu, C. Wu, and S. Fang. 2013. Epidemiological dynamics and phylogeography of influenza virus in southern China. Journal of Infectious Diseases 207: 106-114.

Chretien, J.-P., A. Anyamba, J. Small, S. Britch, J.L. Sanchez, A.C. Halbach, C. Tucker, and K.J. Linthicum. 2015. Global climate anomalies and potential infectious disease risks: 2014-2015. PLoS Current Outbreaks. doi:10.1371/currents.outbreaks. 95fbc4a8fb4695e049baabfc2fc8289f.

Cook, I.G., and T.J.B. Drummer. 2004 Changing health in China: Reevaluating the epidemiological transition model. Health Policy 37: 329-343.

Crosby, A.W. 1986. Ecological imperialism: The biological expansion of Europe 900-1900. New York: Cambridge University Press.

Crosby, A.W. 2003. The Columbian exchange: Biological and cultural consequences of 1492. Westport, CT: Praeger Publishers.

Daszak, P. 2000. Emerging infectious diseases of wildlife: Threats to biodiversity and human health. Science 287: 443-449.

Daszak, P. 2005. Emerging infectious diseases and the socioecological dimension. EcoHealth 2: 239-240.

Daszak, P., A.A. Cunningham, and A.D. Hyatt. 2001. Anthropogenic environmental change and the emergence of infectious diseases in wildlife. Acta Tropica 78: 103-116.

Davis, M. 2005. The monster at our door: The global threat of avian $f l u$. New York: The New Press.

Diamond, J. 1999. Guns, germs, and steel: The Fates of human societies. New York: W. W. Norton \& Company.

Fabre, G., and V.G. Rodwin. 2011. Public health and medical care for the world's factory: China's Pearl River Delta region. BMC Medicine 9: 110.

Fang, L.-Q., S.J. de Vlas, S. Liang, C.W.N. Looman, P. Gong, B. Xu, L. Yan, H. Yang, et al. 2008. Environmental factors contributing to the spread of H5N1 avian influenza in Mainland China. PLoS One 3: e2268.

FAO (Food and Agriculture Organization). 2015. FAOSTAT. Food and Agriculture Organization, Rome. http://faostat.fao.org/. Retrieved 20 Oct 2015.

Fasina, F.O., S.P. Bisschop, and R.G. Webster. 2007. Avian influenza H5N1 in Africa: An epidemiological twist. The Lancet Infectious Diseases 7: 696-697.

Gao, G.F. 2014. Influenza and the live poultry trade. Science 344: 235.

Gilbert, M., X. Xiao, D.U. Pfeiffer, M. Epprecht, S. Boles, C. Czarnecki, P. Chaitaweesub, W. Kalpravidh, et al. 2008. Mapping H5N1 highly pathogenic avian influenza risk in Southeast Asia. Proceedings of the National Academy of Sciences of the United States of America 105: 4769-4774.

Gilbert, M., N. Golding, H. Zhou, G.R. Wint, T.P. Robinson, A.J. Tatem, S. Lai, S. Zhou, et al. 2014. Predicting the risk of avian influenza A H7N9 infection in live-poultry markets across Asia. Nature Communications 5: 4116.

Goldman, A., R. Krider, and S. Ramaswami. 1999. The persistent competitive advantage of traditional food retailers in Asia: Wet markets' continued dominance in Hong Kong. Journal of Macromaketing 19: 126-139.

Gong, P., S. Liang, E.J. Carlton, Q. Jiang, J. Wu, L. Wang, and J.V. Remais. 2012. Urbanisation and health in China. The Lancet 379: 843-852.

Graham, J.P., J.H. Leibler, L.B. Price, J.M. Otte, D.U. Pfeiffer, T. Tiensin, and E.K. Silbergeld. 2008. The animal-human interface and infectious disease in industrial food animal production: 
Rethinking biosecurity and biocontainment. Public Health Reports 123: 282-299.

Hales, S., P. Weinstein, Y. Souares, and A. Woodward. 1999. El Niño and the dynamics of vectorborne disease transmission. Environmental Health Perspectives 107: 99-102.

Hay, S.I., C.A. Guerra, A.J. Tatem, P.M. Atkinson, and R.W. Snow. 2005. Urbanization, malaria transmission and disease burden in Africa. Nature Reviews Microbiology 3: 81-90.

He, Y., P. Lu, S. Tang, Y. Chen, E. Pei, B. Zhao, H. Ren, J. Li, et al. 2014. Live poultry market closure and control of avian influenza A (H7N9), Shanghai, China. Emerging Infectious Diseases 20: $1565-1566$.

Hoetz, P.J. 2012. Engaging a rising China through neglected tropical diseases. PLoS Neglected Tropical Diseases 6: e1599.

Hogerwerf, L., R.G. Wallace, D. Ottaviani, J. Slingenbergh, D. Prosser, L. Bergmann, and M. Gilbert. 2010. Persistence of highly pathogenic avian influenza H5N1 virus defined by agroecological niche. EcoHealth 7: 213-225.

Hulme, P.E. 2009. Trade, transport and trouble: Managing invasive species pathways in an era of globalization. Journal of Applied Ecology 46: 10-18.

Humphries, M.O. 2014. Paths of Infection: the first world war and the origins of the 1918 Influenza Pandemic. War in History 21: $55-81$.

Jannetta, A.B. 1993. Disease ecologies of East Asia. In The Cambridge world history of human disease, ed. K.F. Kiple, 476-482. Cambridge: Cambridge University Press.

Kapan, D.D., S.N. Bennett, B.N. Ellis, J. Fox, N.D. Lewis, J.H. Spencer, S. Saksena, and B.A. Wilcox. 2006. Avian influenza (H5N1) and the evolutionary and social ecology of infectious disease emergence. EcoHealth 3: 187-194.

Khan, K., J. Sears, V.W. Hu, J.S. Brownstein, S. Hay, D. Kossowsky, R. Eckhardt, T. Chim, et al. 2013. Potential for the international spread of middle east respiratory syndrome in association with mass gatherings in Saudi Arabia. PLoS Current Outbreaks. doi:10.1371/currents.outbreaks.a7b70897ac2fa4f79b59f90d24c8 $60 \mathrm{~b} 8$.

Kilpatrick, A.M. 2011. Globalization, land use, and the invasion of the west nile virus. Science 334: 323-327.

Kilpatrick, A.M., A.A. Chmura, D.W. Gibbons, R.C. Fleischer, P.P. Marra, and P. Daszak. 2006. Predicting the global spread of H5N1 avian influenza. Proceedings of the National Academy of Sciences 103: 19368-19373.

Knobler, S., A. Mahmoud, S. Lemon, and L. Pray. 2006. The impact of globalization on infectious disease emergence and control. Washington, DC: National Academies Press.

Kraemer, M.U., M.E. Sinka, K.A. Duda, A.Q. Mylne, F.M. Shearer, C.M. Barker, C.G. Moore, R.G. Carvalho, et al. 2015. The global distribution of the arbovirus vectors Aedes aegypti and Ae. albopictus. ELife 4: e08347.

Langford, C. 2005. Did the 1918-1919 influenza pandemic originate in China? Population and Development Review 31: 473-505.

Langwig, K.E., J. Voyles, M.Q. Wilber, W.F. Frick, K.A. Murray, B.M. Bolker, J.P. Collins, T.L. Cheng, et al. 2015. Context dependent conservation responses to emerging wildlife diseases. Frontiers in Ecology and the Environment 13: 195-202.

Li, X., C. Wang, G. Zhang, L. Xiao, and J. Dixon. 2012a. Urbanisation and human health in China: Spatial features and a systemic perspective. Environmental Science and Pollution Research International 19: 1375-1384.

Li, X.-H., J.-L. Liu, V. Gibson, and Y.-G. Zhu. 2012b. Urban sustainability and human health in China, East Asia and Southeast Asia. Current Opinion in Environmental Sustainability 4: 436-442.

Martin, V., D.U. Pfeiffer, X. Zhou, X. Xiao, D.J. Prosser, F. Guo, and M. Gilbert. 2011. Spatial distribution and risk factors of highly pathogenic avian influenza (HPAI) $\mathrm{H} 5 \mathrm{~N} 1$ in China. PLoS Pathogens 7: e1001308.

McKeown, R.E. 2009. The epidemiologic transition: Changing patterns of mortality and population dynamics. American Journal of Lifestyle Medicine 3: 19S-26S.

McKibbin, W.J., and A. Sidorenko. 2006. Global macroeconomic consequences of pandemic influenza. Sydney: Lowy institute for International Policy.

McMichael, A.J. 1999. Prisoners of the proximate: Loosening the constraints on epidemiology in an age of change. American Journal of Epidemiology 149: 887-897.

McMichael, A.J. 2004. Environmental and social influences on emerging infectious diseases: Past, present and future. Philosophical Transactions of the Royal Society of London. Series B, Biological Sciences 359: 1049-1058.

McNeill, W.H. 1998. Plagues and peoples, 3rd ed. New York: Anchor Books.

Meentemeyer, R.K., S.E. Haas, and T. Vaclavik. 2012. Landscape epidemiology of emerging infectious diseases in natural and human-altered ecosystems. Annual review of Phytopathology 50: 379-402.

Morens, D.M., G.K. Folkers, and A.S. Fauci. 2004. The challenge of emerging and re-emerging infectious diseases. Nature 430: 242-249.

Murphy, F.A. 1999. The threat posed by the global emergence of livestock, food-borne, and zoonotic pathogens. Annals of the New York Academy of Sciences 894: 20-27.

Murray, K.A., and P. Daszak. 2013. Human ecology in pathogenic landscapes: Two hypotheses on how land use change drives viral emergence. Current Opinion in Virology 3: 79-83.

Myers, S.S., L. Gaffikin, C.D. Golden, R.S. Ostfeld, K.H. Redford, T.H. Ricketts, W.R. Turner, and S.A. Osofsky. 2013. Human health impacts of ecosystem alteration. Proceedings of the National Academy of Sciences of the United States of America 110: $18753-18760$.

NBS (National Bureau of Statistics of China). 2015. China statistical yearbook 2015. Beijing: China Statistics Press.

Parlak, E. 2015. Middle east respiratory syndrome: MERS. Journal of Microbiology and Infectious Diseases 5: 93-98.

Patel, R.B., and T.F. Burke. 2009. Urbanization-An emerging humanitarian disaster. The New England Journal of Medicine 361: 741-743.

Patz, J.A., P. Daszak, G.M. Tabor, A.A. Aguirre, M. Pearl, J. Epstein, N.D. Wolfe, A.M. Kilpatrick, et al. 2004. Unhealthy landscapes: Policy recommendations on land use change and infectious disease emergence. Environmental Health Perspectives 112: 1092-1098.

Paul, M., S. Tavornpanich, D. Abrial, P. Gasqui, M. Charras-Garrido, W. Thanapongtharm, X. Xiao, M. Gilbert, et al. 2010. Anthropogenic factors and the risk of highly pathogenic avian influenza H5N1: Prospects from a spatial-based model. Veterinary Research 41: 28.

Peng, X. 2011. China's demographic history and future challenges. Science 333: 581-587.

Perrings, C. 2010. Exotic effects of capital accumulation. Proceedings of the National Academy of Sciences of the United States of America 107: 12063-12064.

Perrings, C. 2014. Our uncommon heritage: Biodiversity, ecosystem services and human wellbeing. Cambridge: Cambridge University Press.

Perrings, C., C. Castillo-Chavez, G. Chowell, P. Daszak, E. Fenichel, D. Finnoff, R. Horan, A.M. Kilpatrick, et al. 2014. Merging economics and epidemiology to improve the prediction and management of infectious disease. EcoHealth 11: 464-475.

Perrings, C., K. Dehnen-Schmutz, J. Touza, and M. Williamson. 2005. How to manage biological invasions under globalization. Trends in Ecology \& Evolution 20: 212-215. 
Pi, C., Z. Rou, and S. Horowitz. 2014. Fair of fowl? Industrialization of poultry production in China. In Global meat complex: the China series, ed. S. Sharma, and B. Lilliston. Minneapolis: Institute for Agriculture and Trade Policy.

Piao, S., P. Ciais, Y. Huang, Z. Shen, S. Peng, J. Li, L. Zhou, H. Liu, et al. 2010. The impacts of climate change on water resources and agriculture in China. Nature 467: 43-51.

Pike, J., T. Bogich, S. Elwood, D.C. Finnoff, and P. Daszak. 2014. Economic optimization of a global strategy to address the pandemic threat. Proceedings of the National Academy of Sciences of the United States of America 111: 18519-18523.

Potter, C.W. 2001. A history of influenza. Journal of Applied Microbiology 91: 572-579.

Prosser, D.J., P. Cui, J.Y. Takekawa, M. Tang, Y. Hou, B.M. Collins, B. Yan, N.J. Hill, et al. 2011. Wild bird migration across the Qinghai-Tibetan plateau: A transmission route for highly pathogenic H5N1. PLoS ONE 6: e17622.

Rees, M. 2013. Denial of catastrophic risks. Science 339: 1123.

Reisen, W.K. 2010. Landscape epidemiology of vector-borne diseases. Annual Review of Entomology 55: 461-483.

Robinson, T.P., G.W. Wint, G. Conchedda, T.P. Van Boeckel, V. Ercoli, E. Palamara, G. Cinardi, L. D'Aietti, S.I. Hay, and M. Gilbert. 2014. Mapping the global distribution of livestock. PloS One 9: e96084.

Sepulveda, J., and C. Murray. 2014. The state of global health in 2014. Science 345: 1275-1278.

Singh, R.K., M. Hosamani, V. Balamurugan, V. Bhanuprakash, T.J. Rasool, and M.P. Yadav. 2007. Buffalopox: An emerging and reemerging zoonosis. Animal Health Research Reviews 8: 105-114.

Takekawa, J.Y., S.H. Newman, X. Xiao, D.J. Prosser, K.A. Spragens, E.C. Palm, B. Yan, T. Li, et al. 2010. Migration of waterfowl in the East Asian flyway and spatial relationship to HPAI H5N1 outbreaks. Avian Diseases 54: 466-476.

Tatem, A.J., S.I. Hay, and D.J. Rogers. 2006. Global traffic and disease vector dispersal. Proceedings of the National Academy of Sciences of the United States of America 103: 6242-6247.

Taubenberger, J.K., and D.M. Morens. 2006. 1918 Influenza: The mother of all pandemics. Emerging Infectious Diseases 12: $15-22$.

Taylor, L.H., S.M. Latham, and M.E.J. Woolhouse. 2001. Risk factors for human disease emergence. Philosophical Transactions of the Royal Society of London B 356: 983-989.

Tong, M.X., A. Hansen, S. Hanson-Easey, S. Cameron, J. Xiang, Q. Liu, Y. Sun, P. Weinstein, et al. 2015. Infectious diseases, urbanization and climate change: Challenges in future China. International Journal of Environmental Research and Public Health 12: 11025-11036.

UN (United Nations). 2015. UN data. United Nations, New York. http://data.un.org/. Retrieved 15 Oct 2015.

Venkatesan, G., V. Balamurugan, M. Prabhu, R. Yogisharadhya, D.P. Bora, P.N. Gandhale, M.S. Sankar, A.M. Kulkarni, et al. 2010. Emerging and re-emerging zoonotic buffalopox infection: A severe outbreak in Kolhapur (Maharashtra), India. Veterinaria Italiana 46: 439-448.

Voyles, J., A.M. Kilpatrick, J.P. Collins, M.C. Fisher, W.F. Frick, H. McCallum, C.K.R. Willis, D. Blehert, et al. 2014. Beyond too little, too late: Managing emerging infectious diseases requires international action. EcoHealth 12: 404-407.

Wagner, D.M., J. Klunk, M. Harbeck, A. Devault, N. Waglechner, J.W. Sahl, J. Enk, D.N. Birdsell, et al. 2014. Yersinia pestis and the Plague of Justinian 541-543 AD: A genomic analysis. The Lancet Infectious Diseases 14: 319-326.

Wallace, R.G., L. Bergmann, and L. Hogerwerf. 2010. Are influenzas in Southern China byproducts of the region's globalising historical present. In Influenza and public health: learning from past pandemics, ed. T. Giles-Vernick, and S. Craddock, 101-144. New York: Eartscan.

Wang, L., Y. Wang, S. Jin, Z. Wu, D.P. Chin, J.P. Kaplan, and M.E. Wilson. 2008. Emergence and control of infectious diseases in China. The Lancet 372: 1598-1605.

Weaver, S.C. 2013. Urbanization and geographic expansion of zoonotic arboviral diseases: Mechanisms and potential strategies for prevention. Trends in Microbiology 21: 360-363.

Webby, R.J., and R.G. Webstter. 2003. Are we ready for pandemic influenza. Science 302: 1519-1522.

Webster, R.G. 2004. Wet markets-A continuing source of acute respiratory syndrome and influenza? The Lancet 363: 234-236.

Wei, J., A. Hansen, Y. Zhang, H. Li, Q. Liu, Y. Sun, S. Xue, S. Zhao, et al. 2014. The impact of climate change on infectious disease transmission: Perceptions of CDC health professionals in Shanxi Province, China. PLoS One 9: e109476.

Weiss, R.A., and A.J. McMichael. 2004. Social and environmental factors in the emergence of infectious diseases. Nature Medicine 10: S70-S76.

Westcott, P., R. Trostle. 2014. USDA Agricultural Projections to 2023, pp. OCE-2014-2011. United States Department of Agriculture, Washington, D.C.

Woo, P.C.Y., S.K.P. Lau, and K.-Y. Yuen. 2006. Infectious diseases emerging from Chinese wet-markets: Zoonotic origins of severe respiratory viral infections. Current Opinion in Infectious Diseases 19: 401-407.

World Bank. 2016. World development indicators. World Bank, Washington, D.C.

Yang, G., L. Kong, W. Zhao, X. Wan, Y. Zhai, L.C. Chen, and J.P. Koplan. 2008. Emergence of chronic non-communicable diseases in China. The Lancet 372: 1697-1705.

Yu, H., Z. Feng, X. Zhang, N. Xiang, Y. Huai, L. Zhou, Z. Li, C. Xu, et al. 2007. human influenza A (H5N1) cases, urban areas of the People's Republic of China, 2005-2006. Emerging Infectious Diseases 13: 1061-1064.

Yu, H., J.T. Wu, B.J. Cowling, Q. Liao, V.J. Fang, S. Zhou, P. Wu, H. Zhou, et al. 2014. Effect of closure of live poultry markets on poultry-to-person transmission of avian influenza A H7N9 virus: An ecological study. The Lancet 383: 541-548.

Zhang, S.-Y., L. Yu, and P. Daszak. 2008. EcoHealth and the black death in the year of the rat. EcoHealth 5: 99-100.

Zhu, Y.-G., J.P.A. Ioannidis, H. Li, K.C. Jones, and F.L. Martin. 2011. Understanding and harnessing the health effects of rapid urbanization in china. Environmental Science and Technology 45: 5099-5104.

Zumla, A., D.S. Hui, and S. Perlman. 2015. Middle east respiratory syndrome. The Lancet 386: 995-1007.

\section{AUTHOR BIOGRAPHIES}

Tong Wu $(\square)$ is a doctoral candidate in the School of Life Sciences at Arizona State University, as well as a visiting scholar in the School of Public Policy and Management at Tsinghua University. His primary research interests include the economics of infectious diseases, ecosystem management, and climate change and energy policy.

Address: School of Life Sciences, Arizona State University, LSA 123, 427 East Tyler Mall, Tempe, AZ 85287, USA.

e-mail: twu11@asu.edu

Charles Perrings is a professor of Environmental Economics in the School of Life Sciences at Arizona State University. His research interests include the economics of biodiversity, the spread of pests and pathogens, and ecosystem services. He is the co-director of the ecoSERVICES Group, with Ann Kinzig, and a fellow of the Beijer Institute of Ecological Economics. 
Address: School of Life Sciences, Arizona State University, LSA 127, 427 East Tyler Mall, Tempe, AZ 85287, USA.

e-mail: charles.perrings@asu.edu

Ann Kinzig is a professor in the School of Life Sciences and the School of Sustainability at Arizona State University. She is also the chief research strategist for the Global Institute of Sustainability at ASU. Her research interests include ecosystem services, biodiversity, and the spread of pests and pathogens.

Address: School of Life Sciences, Arizona State University, LSA 124, 427 East Tyler Mall, Tempe, AZ 85287, USA.

Address: Global Institute of Sustainability, Arizona State University, 800 South Cady Mall, Tempe, AZ 85287, USA.

e-mail: ann.kinzig@asu.edu

James P. Collins is the Virginia Ullman Professor of Natural History and the Environment in the School of Life Sciences at Arizona State University. His research interests include evolutionary ecology and conservation biology, particularly focused on amphibians, as well as infectious diseases and environmental ethics.

Address: School of Life Sciences, Arizona State University, LSC 402, 427 East Tyler Mall, Tempe, AZ 85287, USA.

e-mail: jcollins@asu.edu
Ben A. Minteer is the Arizona Zoological Society Professor of Environmental Ethics and Conservation in the School of Life Sciences at Arizona State University. His research interests cover environmental ethics and policy, as well as the history of conservation thought and practice, particularly in the United States.

Address: School of Life Sciences, Arizona State University, LSA 262, 427 East Tyler Mall, Tempe, AZ 85287, USA.

e-mail: ben.minteer@asu.edu

Peter Daszak is the President of EcoHealth Alliance, an international nonprofit organization focused on research and public education based in New York City. His primary research interests include disease ecology and conservation medicine, and he has studied a wide variety of zoonoses, including SARS, avian influenzas, and Ebola. Address: EcoHealth Alliance, 460 West 34th Street - 17th Floor, New York, NY 10001, USA.

e-mail: daszak@ecohealthalliance.org 